Pesq. Vet. Bras. 29(10):788-792, outubro 2009

\title{
Morphological aspects of buffaloes (Bubalus bubalis) umbilical cord ${ }^{1}$
}

\author{
Guilherme J. Ferreira ${ }^{2}$, Érika Branco ${ }^{5}$, Rosa Cabral ${ }^{4}$, Guilherme B. Gregores ${ }^{4}$, \\ Emerson T. Fioretto ${ }^{4}$, Ana Rita de Lima ${ }^{4}$, Carlos Alberto P. Sarmento ${ }^{4}$, Maria \\ Angelica Miglino ${ }^{4}$ and Ana F. Carvalho ${ }^{3}$
}

\begin{abstract}
Ferreira G.J., Branco E., Cabral R., Gregores G.B., Fioretto E.T., Lima A.R., Sarmento C.A.P., Miglino M.A. \& Carvalho A.F. 2009. Morphological aspects of buffaloes (Bubalus bubalis) umbilical cord. Pesquisa Veterinária Brasileira 29(10):788792. Faculdade de Medicina Veterinária e Zootecnia, Universidade Federal Rural da Amazônia (UFRA), Av. Pte. Tancredo Neves 2501, Montese, Belém, PA 66077-530, Brazil. E-mail: erika.branco@ufra.edu.br

Buffalo is an important livestock resource, with a great participation in agricultural systems, providing milk, meat, and work power. Umbilical cord is responsible for maternalfetal nutrients exchange during pregnancy, and its alterations can compromise the fetal development. We investigated ten pregnant uteruses collected from cross-bread buffaloes in different stages of gestation. Pregnancy and fetal age was determined by measuring the apex sacral length and development period was calculated by previously published formula. Umbilical cords were measured for length determination. Umbilical cord vascular net and anastomosis were observed by injection of Neoprene latex. Histological sections of the umbilical cord were studied after stain with $\mathrm{HE}$, picrossirius, toluidine blue, orceine, and PAS reaction. Buffaloes' umbilical cord was formed by two central arteries, an allantois duct and two peripheral veins. The artery wall was composed by large quantity of collagen, elastic fibers, fibroblasts and large number of vasa vasorum. The allantois duct was located between the arteries and presented a great number of small nourishing vessels. Small nourishing vessels should be carefully considered to avoid to be mistaken to the arterials and veins vasa vasorum. Medium length of umbilical cord from buffalos was $11.8 \mathrm{~cm}$ (minimum of $6.8 \mathrm{~cm}$ and maximum of $17.4 \mathrm{~cm}$ ).
\end{abstract}

INDEX TERMS: Buffalo, umbilical cord, gross anatomy, microscopy.

RESUMO.- [Aspectos Morfológicos do cordão umbilical de búfalos (Bubalus bubalis).] Búfalo é uma importante fonte de recurso nos rebanhos animais, apresentando uma grande participação na agropecuária, proven-

\footnotetext{
${ }^{1}$ Received on August 1, 2008.

Accepted for publication on May 16, 2009.

2 Universidade Federal do Piauí (UFPI), Campus Universitário, BR135 Km 3, Bom Jesus, PI 64900-000, Brazil.

${ }^{3}$ Faculdade de Medicina Veterinária e Zootecnia, Universidade Federal Rural da Amazônia (UFRA), Av. Pte. Tancredo Neves 2501, Montese, Belém, PA 66077-530, Brazil. *Corresponding author: erika.branco@ufra.edu.br

${ }^{4}$ Faculdade de Medicina Veterinária e Zootecnia (FMVZ), Universidade de São Paulo (USP), Av. Prof. Dr. Orlando Marques de Paiva 87, Cidade Universitária, São Paulo, SP 05508-270, Brazil.

${ }^{5}$ Centro Universitário, Fundação de Ensino Octávio Bastos-Unifeob, Av. Dr. Octávio Bastos s/n, Jardim Nova São João, São João da Boa Vista, SP 13870-000, Brazil.
}

do leite, carne e força de trabalho. O Cordão umbilical é responsável pela troca de nutrientes materno-fetais durante a gestação, e suas alterações podem comprometer o desenvolvimento fetal. Nós investigamos dez úteros gravídicos de búfalos de raças cruzadas em fases diferentes de gestação. O período de gestação e a idade fetal foram determinados pelo comprimento ápice sacral, aplicando fórmulas previamente estabelecidas. Posteriormente mediu-se o comprimento do cordão umbilical. A rede vascular do cordão umbilical e anastomoses foram observadas por injeção ou látex de neoprene. O cordão umbilical foi estudado a partir de cortes histológicos, corados por HE, picrossirius, azul de Toluidina, orceína e reação histoquímica de PAS. O cordão umbilical de búfalos é formado por duas artérias centrais, ducto alantóide e duas veias periféricas e apresentam forma de ampulheta. A parede da artéria umbilical é composta por grande quan- 
tidade de fibras colágenas e elásticas, fibroblastos e um grande número de vasa vasorum. O ducto alantóide fica alocado entre as artérias e apresenta um grande número de pequenos vasos nutritivos. Os vasos nutritivos devem ser cuidadosamente identificados para evitar-se confundi-los com vasa vasorum. O comprimento médio do cabo de cordão umbilical dos búfalos era $11.8 \mathrm{~cm}$ (mínimo de $6.8 \mathrm{~cm}$ e máximo de $17.4 \mathrm{~cm}$ ).

TERMOS DE INDEXAÇÃO: Búfalo, cordão umbilical, anatomia macroscópica e microscópica.

\section{INTRODUCTION}

Buffalo is an important livestock resource, presenting great participation in agricultural systems, providing milk, meat, and work power. Buffaloes belong to the family Bovidae, sub-family Bovinea, which is divided in four genders: Bos (bovine), Bubalus (Asiatic Buffaloes), Synceros (African Buffaloes) and Bison (Bison). Buffaloes are animals of easy adaptation to the tropical or subtropical climatic conditions.

Umbilical cord is responsible for fetus-mother nutrients exchange during the gestation. Morphological or junctional alterations can compromise the fetal development, because fetus-mother nutrients exchange is very delicate. In ruminant, the umbilical vessels leaving the fetus ramify in the corium originating around 60 to 80 branches to compose the fetal cotyledons. Cotyledons were equally proportional to the number of uterine caruncles. Nurture was based on a filtrate of mother's blood when passing by the uterine caruncles (Montané \& Bourdelle 1917) in proximity to the fetus circulation.

The umbilical cord in buffaloes was composed by 2 thick arteries and 2 thin veins. Anastomosis and inter connecting branches between umbilical arteries were presented at the level of the cotyledons. Umbilical vessels presented exceptional vascular structure. They were characterized by inner longitudinal and outer circular muscle fibers. Moreover, they presented uniform distribution of elastic fibers forming a sphincter. The sphincter was responsible to avoid hemorrhages in cases of rupture. The veins at later stages of gestation did not differ from the arteries in their histological feature (AbdelRaouf \& El Nagar 1968, Ribeiro \& Miglino 1997a)

Based on the advanced participation of the buffaloes in the agriculture economy, like as milk production related to mammary gland morphology (Santos et al. 2007) it is necessary detailed knowledge about its reproductive biology like fetal membranes development during early stages of pregnancy (Morini et al. 2008). This knowledge would guarantee the improvement of the herd and the increase in the number of production and consequently expanding the national farming economy.

The objectives for this study were analyze the gross and microscopic features from umbilical cord of buffalos, as length, diameter, place of insertion on fetus, presence of anastomosis as inter arterials or arteriovenous.
Moreover, information of buffalo prenatal development would be essential for studying factors that causes alterations on the normal development (Eid 2004).

\section{MATERIALS AND METHODS}

\section{Animals}

In this study were used ten pregnant uteruses collected from cross-bread buffaloes in different stage of gestation. Samples $(n=10)$ were acquired from different slaughterhouses in different parts of Brazil. The period of pregnancy was determined applying previously established formulas (Abdel-Raouf \& El-Naggar 1968). We applied two different formula, one for fetuses with less than $20 \mathrm{~cm}(Y=29+(9 / 2) X)$ and another for fetuses with more than $20 \mathrm{~cm}(y=74+(9 / 4) X)$. In which $X$ is the apex sacral length (A-S), equivalent to the distance of the head's highest point until the tail base, accompanying the curvature of the body and $Y$ is related to the age.

After removing the fetal membranes it was made the A-S measuring to help the age determination and the measuring of the umbilical cord length was taken. Fetus (one bovine and one buffalo) was submitted to the injection of Neoprene latex 650 colored in green for veins, yellow for allantois duct and red for arteries. After latex injection, the umbilical cord and abdomen fetus was dissected to analyze the presence of inter arterial anastomosis and check the confluence point between umbilical veins.

Only the buffaloes' umbilical cords were fixed in formaldehyde $10 \%$, PBS $0.1 \mathrm{M}, \mathrm{pH} 7.4$, and processed for histology in accordance to standard protocols. Paraplast embedded was done and sections of $4 \mu \mathrm{m}$ were obtained and stained with HE, picrossirius, toluidine blue, orceine, and PAS reaction. The sections were analyzed and images taken with the aid of analysis image software.

\section{RESULTS}

\section{Measurement}

Measuring data of weight, length, perimeters of three regions (juxtafetal, medium and juxta-placental), apexsacral (A-S) axis, and antimere identification of pregnant horn are described in Table 1. The longitudinal growth and thickness increase of the umbilical cord was proportional

Table 1. Table exhibiting the measuring data obtained from the pregnant uterus, and the estimative of age

\begin{tabular}{|c|c|c|c|c|c|c|c|c|c|}
\hline \multirow[t]{4}{*}{ Anime } & \multicolumn{2}{|c|}{ Fetal Pregnant } & \multirow{4}{*}{$\begin{array}{c}\text { Age } \\
\text { estimative } \\
\text { (days) }\end{array}$} & \multicolumn{6}{|c|}{ Measurements } \\
\hline & \multirow[t]{3}{*}{ Sex } & \multirow[t]{3}{*}{ Horn $^{a}$} & & \multicolumn{3}{|c|}{ Umbilical cord } & \multirow{2}{*}{\multicolumn{3}{|c|}{$\frac{\text { Region }}{\text { perimeter }^{\mathrm{d}}(\mathrm{cm})}$}} \\
\hline & & & & \multirow{2}{*}{$\frac{\bar{A}-\mathrm{S}^{\mathrm{C}}}{(\mathrm{cm})}$} & \multicolumn{2}{|c|}{ Weight Length } & & & \\
\hline & & & & & (4) & $(\mathrm{sm})$ & $\mathrm{JF}$ & $\mathrm{M}$ & $J P$ \\
\hline 1 & & L & & & & & & 5.90 & \\
\hline 2 & & & & .00 & & & & 7.40 & \\
\hline 3 & & & & 0 & 9 & & & 9.00 & \\
\hline 4 & & & & 0 & & & & 7.20 & 11. \\
\hline 5 & & $\mathrm{~L}$ & & 46.00 & 36 & & & 6.40 & 7.20 \\
\hline 6 & & L & & 34.00 & 4 & & 0 & 5.10 & 6.90 \\
\hline 7 & & & & 54.00 & 47.57 & & 20 & 7.00 & 9.30 \\
\hline 8 & & 1 & & 26.00 & 7.88 & & & 3.60 & 4.50 \\
\hline g & $\Gamma$ & 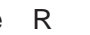 & & 27.00 & 15.72 & & 00 & 4.60 & 5.90 \\
\hline 2 & & 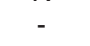 & 181.00 & & 48.83 & 11.80 & 6.34 & 6.24 & 8.52 \\
\hline
\end{tabular}

a L: left / R: right; ${ }^{b} y=29+(9 / 2) X<$ fetus $20 \mathrm{~cm}<y=74+(9 / 4) X ;{ }^{c} A-S$ : apex sacral axis; d JF: juxtafetal / M: medium / JP: juxtaplacental. 
Table 2. Table demonstrating the correlation among the measures obtained from umbilical cord of the pregnant uterus and the AS axis, estimative of age and umbilical cord weight

\begin{tabular}{|c|c|c|c|c|c|c|}
\hline \multirow[t]{3}{*}{$\mathrm{AS}^{\mathrm{a}}$} & \multirow[t]{3}{*}{ Age } & \multirow[t]{3}{*}{$\mathrm{PF}^{\mathrm{b}}$} & \multicolumn{4}{|c|}{ Umbilical cordc } \\
\hline & & & \multirow[t]{2}{*}{ Length } & & um & nce \\
\hline & & & & $\mathrm{JF}$ & $M$ & $\mathrm{JP}$ \\
\hline
\end{tabular}

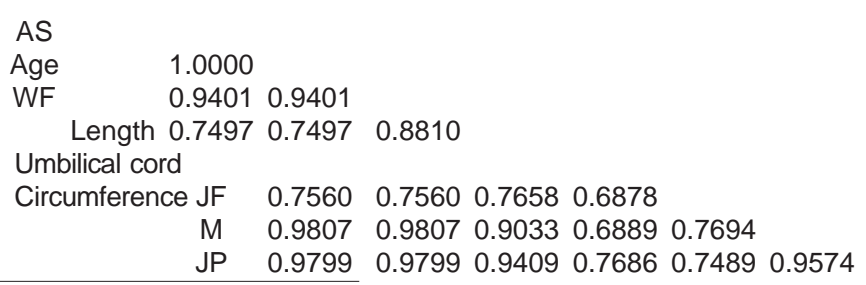

a A-S: apex sacral axis, b Umbilical cord weight, c JF: juxtafetal / M: medium / JP: juxtaplacental.

to the fetus growth (Table 2). Medium length of umbilical cord from buffalos was $11.8 \mathrm{~cm}$ (minimum of $6.8 \mathrm{~cm}$ and maximum of $17.4 \mathrm{~cm}$ ). All correlations presented medium and high rates $(\geq 0.685)$, demonstrating a positive interaction to the growth, what lead us to infer the existence of a factor that allows to predict the umbilical cord length in function of the fetal length.

\section{Buffaloes' umbilical cord gross anatomy}

Buffaloes' umbilical cord presented a sandglass shape (Fig.1A), where the middle portions were narrowed in comparison to the juxtafetal and juxtaplacental portions. The juxtaplacental portion was larger than the juxtafetal portion. No anastomosis was detected in the buffaloes' umbilical cord.

Moreover, buffaloes' umbilical cord was formed by two central arteries, an allantoids duct and two peripheral veins.

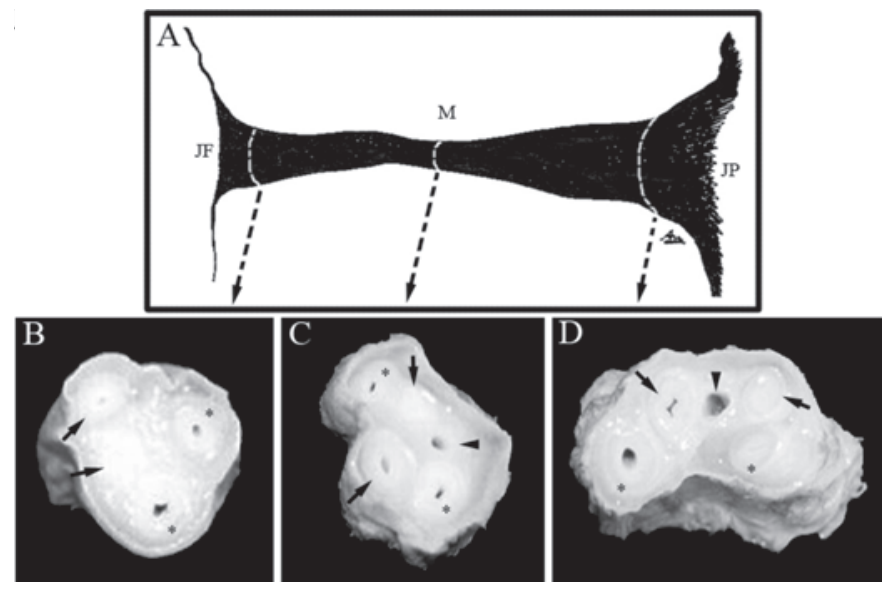

Fig.1. (A) Schematic drawing of the sandglass shape of the buffalo umbilical cord and the levels of sections (dotted arrow) of the JF (juxtafetal), M (middle) and JP (juxta-placental) regions. (B) JF region with parallel distribution of the arteries (arrows) and veins $\left(^{*}\right)$. (C) M region with the arteries (arrows), veins $\left(^{*}\right)$, allantoids duct (arrow head), and the inverted crux shape. (D) JP region of the umbilical cord with isosceles trapezoid shape and arteries (arrows), veins $\left({ }^{*}\right)$, and allantoids duct (arrow head).
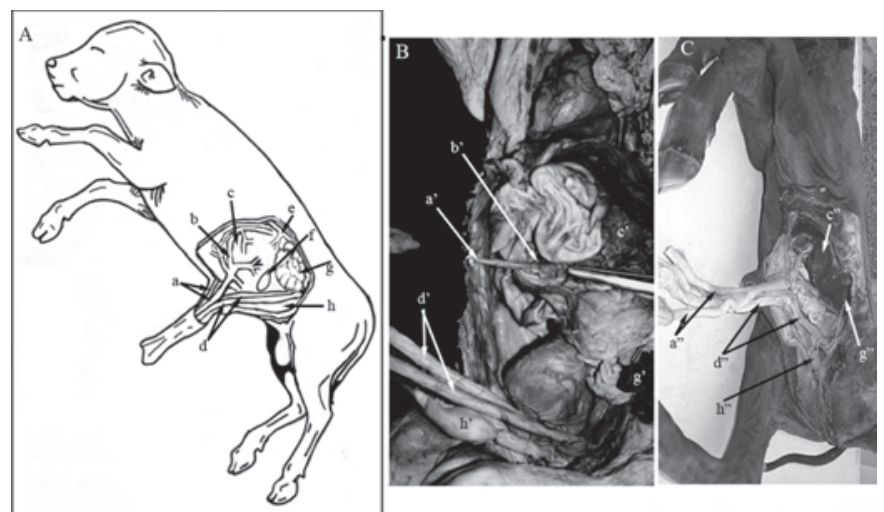

Fig.2. Comparative montage between bovine $(\mathbf{A}, \mathbf{B})$ and buffalo's (C) fetus injected with neoprene latex, and a schematic representative drawing (A-C): a, a', a" = umbilical vein; b, b' = venous duct; c, c', c" = liver; $d, d$, d" = umbilical arteries; e = abdominal aorta; $f$ = biliar vesicle; $g, g^{\prime}, g$ " = kidney; $h, h^{\prime}$, $\mathrm{h} "=$ allantoids duct.

In the juxtafetal portions, the vases presented a line parallel disposition (Fig.1B), while in the medium portion the arrangement was similar to inverted crux constellation (Fig.1C), meanwhile in the juxta-placental portion the vessels were displaced in isosceles trapezoid organization (Fig.1D). The two umbilical veins fused in the abdominal cavity close to the liver in the buffaloes' fetuses (Fig.2C). The umbilical arteries were originated from the distal portion the abdominal aorta and directed through the juxtaplacental portion to the placentomes forming a vary number of ramifications. The allantois duct was originated in the bladder cranial pole, opening in the allantois sac right after the juxtaplacental region.

\section{Bovine umbilical cord gross anatomy}

Bovine umbilical cord showed anastomosis between veins in the juxtafetal portion, and inter-arterial anastomosis in the juxtaplacental portion (Fig.2A, 2B). Bovine fetuses' umbilical veins fused at the level of juxtafetal portion of the umbilical cord. Umbilical arteries arise from the internal celiac arteries, while the umbilical veins proceed to the interior of the fetus towards the liver and many of those small vessels act as vasa vasorum, nourishing the allantois duct. These umbilical vessels lay parallels to the umbilical cord, presenting a spiraled disposition, where the arteries surround the veins, which are more flexuous. This disposition is attributed to the movement of the fetus inside the amnion. The umbilical vessels are muscular type, in other words, they present the medium tunic rich with smooth muscular fibers, forming a sphincter that produces the occlusion of the vessels when occurs the rupture of the umbilical cord avoiding hemorrhages.

\section{Microscopy}

Microscopic investigation revealed the funicular vessels and allantois duct of buffalo and bovine showing central arteries with star shaped lumen, muscular layers, and fu- 
nicular vein with symmetrical lumen and allantois duct (Fig.3A-C).

The artery wall was composed by large quantity of collagen, elastic fibers, fibroblasts and large number of vasa vasorum (Fig.3E). The allantois duct is located between the arteries and presented a great number of small nourishing vessels for a possible vascular supply and not to be considering as a mistake related to the arterials and veins vasa vasorum. All the structures compounding the umbilical cord were wrapped by the umbilical mesenchyme (Fig.3D), constituted by mucous connective tissue limited by the amnion. The most external wall of the umbilical

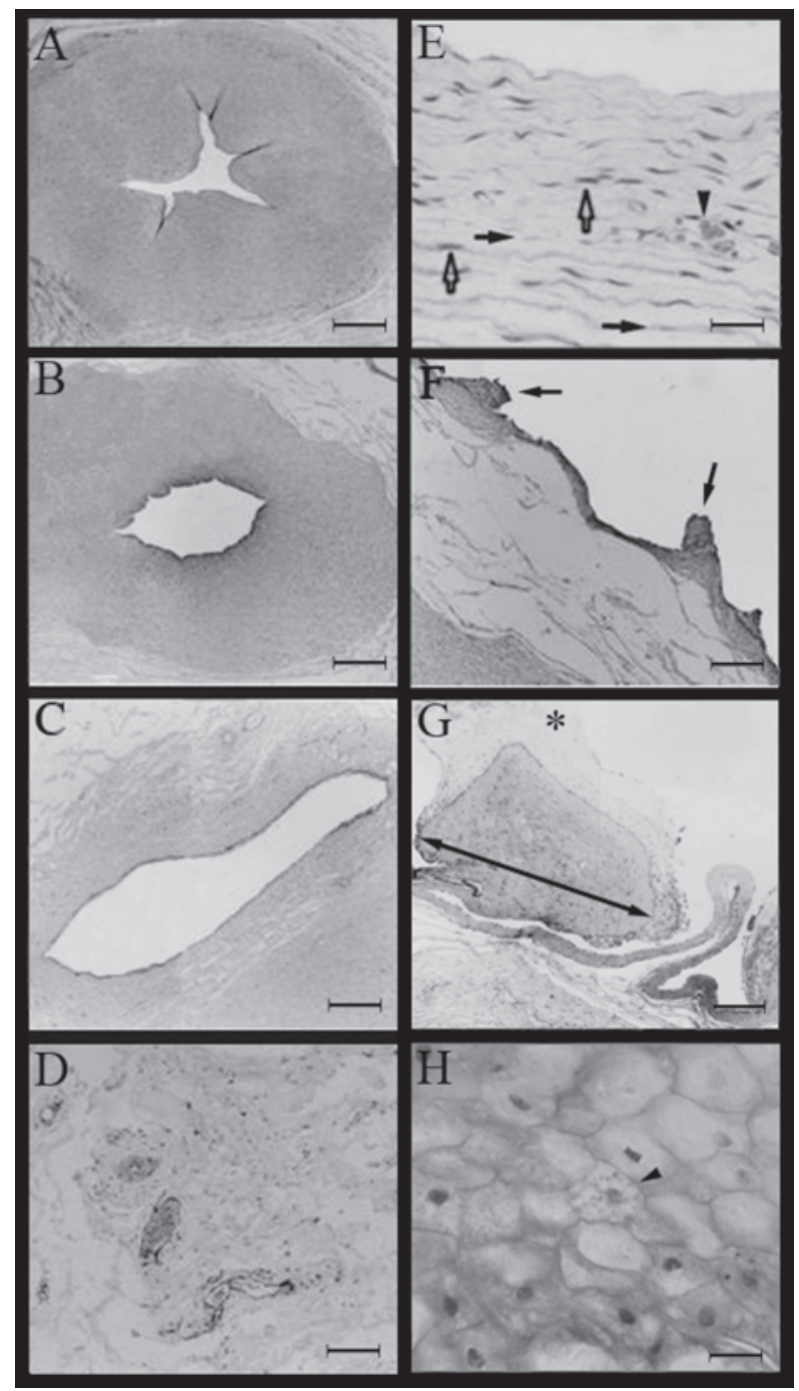

Fig.3. Photomicrography of buffalo umbilical cord showing (A) umbilical artery, (B) funicular vein, (C) allantois duct, (D) umbilical mesenchyme, (E) Medium tunic exhibiting vasa vasorum (arrow heads), collagen fibers (black arrows) and fibroblasts (open arrows), (F) Verrucous epithelial papillae (black arrows) in the amniotic epithelia, (G) cover of epithelium umbilical cord $\left(^{*}\right)$ and verrucous epithelia papillae (double head arrow), $(\mathbf{H})$ globoid cells with glycogen (arrow head). Stain: $H E(A-G)$ and $P A S$ reaction $(H)$. Bar scale: $20 \mu \mathrm{m}(\mathrm{A}-\mathrm{C}) ; 40 \mu \mathrm{m}(\mathrm{D}, \mathrm{E}, \mathrm{G}, \mathrm{H}) ; 200 \mu \mathrm{m}(\mathrm{F})$. cord was composed by the amnion, where it was possible to identify cells of the amniotic epithelia like as verrucous epithelial papillae (Fig.3F-G), where globoid cells with glycogen granule were observed (Fig.3H).

\section{DISCUSSION}

\section{Gross anatomy}

Umbilical cord from buffalos possesses two arteries and two veins wrapped by umbilical mesenchima and covered by amnion. Macroscopic results are similar to descriptions by Montané \& Bourdelle (1917) in ruminants and ovine. Medium length of umbilical cord from buffalos at middle pregnancy was $11.8 \mathrm{~cm}$ (minimum of $6.8 \mathrm{~cm}$ and maximum of $17.4 \mathrm{~cm}$ ), meanwhile, opposing to Barone (1986), who described a $50 \mathrm{~cm}$ total length of umbilical cord in bovine at term. Our result is more similar to descriptions of Barclay et al. (1994) in ovine, demonstrating length around $25 \mathrm{~cm}$. However, we believe, it would not be suitable any degree of comparison between buffaloes and ovine due to the species' characteristics.

Comparison between buffaloes and bovines umbilical cord reveals no changes in the vessels disposition and distribution (Barone 1986, Miglino 1994, Feitosa Jr 1997, Ribeiro 1997a,b). Inter-arterials and inter-venous anastomosis was not observed in umbilical cord of buffaloes, although, in bovine was possible to observe anastomosis between veins in the juxtafetal portion, and inter-arterial anastomosis in the juxta placental portion. Results obtained in bovine's umbilical cord are in agreement to Ribeiro, 1997 in a study developed also in bovine.

Allantois duct was present in all regions of umbilical cord and fetal age from buffalos in accordance to Noden (1985). Two umbilical veins were present in all fetal age in buffaloes differing to the descriptions of Barone (1986) in bovine, who demonstrated the regression of the right vein. In both species the umbilical cord reach to the fetus direction in agreement to William \& Latshaw (1987). Umbilical cord of buffalos was composed by two veins along to the juxtafetal region according to Feitosa Jr (1997) who demonstrated fusion of the veins at one or two centimeters before arriving the liver. Buffalos' umbilical cord demonstrated lined distribution, differing to bovine that presented a spiraled orientation as described by Barone (1986).

\section{Microscopy}

Microscopic study demonstrated two arteries and two veins of the umbilical cord presented a well developed medium muscular layer. Arteries demonstrated a star shape lumen, while veins were in elliptic shape with smooth lumen surface. These results are in agreement to Barone (1986), Feitosa Jr (1997), Miglino et al. (1994) in Holstein bovines and Ribeiro (1997a,b) in zebu cows. Meanwhile, our results are also similar to a detailed description made by Miglino et al. (2007) comparing cows and cloned cattle umbilical cord. 
Buffalo's allantois duct morphology are in agreement to the citation made by Feitosa Jr (1986), and is similar between zebu cows described by Ribeiro (1997), and in Holstein bovines according to Miglino (1994).

In accordance to Barone (1986), the presence of glycogen in cells that composes the epithelia - plaques of squamous metaplasia, were also observed in buffalos. We believe that the papilla along the umbilical cord of buffalos carries inclusions of glycogen for posterior growth of the umbilical cord diameter. The surface of the umbilical cord was covered by simple squamous epithelium. The surface accretions were plaques of squamous metaplasia. They were invested with stratified squamous epithelium in accordance to da Silva et al. (2007) in placentation in Dolphins and Carter et al. (2008) when described that the amnion in Amazonian manatee (Trichechus inunguis) showed the inner surface was lined by simple squamous epithelium. The outer surface was covered by stratified squamous epithelium with regions of squamous metaplasia.

\section{CONCLUSION}

Based on the analysis of the buffalo umbilical cord in comparison with the bovine umbilical cord, we can infer that although edxist some similarities between both species, the umbilical cord of the buffalo behaviors differently in some aspects, as demonstrated by the total extension of the two funicular arteries and the lined disposition of the umbilical vessel. We believe that buffalo umbilical cord in comparison with the bovine one demonstrated a not well evolution adapted development. Based on this, the study could contribute to further reproductive investigation in buffalo either in standard reproduction or in vitro fertilization.

\section{REFERENCES}

Abdel-Raouf M. \& El Nagar M.A. 1968. Biometry of the Egyptian buffalo foetus. J. Vet. Sci. 5(1):37-43.

Barclay A.E., Franklin K.J. \& Prichard M.M.L. 1994. The Foetal Circulation and the Cardiovascular System and the Changes that they undergo at Birth. Charles C. Thomas, Springfield, p.119-49.
Barone R. 1986. Anatomic Comparée des Mammiferes Domestiques.

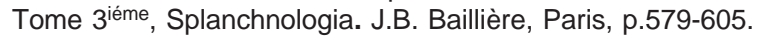

Carter A.M., Miglino M.A., Ambrosio C.E., Santos T.C., Rosas F.C., Neto J.A., Lazzarini S.M., Carvalho A.F. \& da Silva V.M. 2008. Placentation in the Amazonian manatee (Trichechus inunguis). Reprod. Fertil. Dev. 20(4):537-545.

Da Silva V.M., Carter A.M., Ambrosio C.E., Carvalho A.F., Bonatelli M., Lima M.C. \& Miglino M.A. 2007. Placentation in dolphins from the Amazon River Basin: The Boto, Inia geoffrensis, and the Tucuxi, Sotalia fluviatilis. Reprod. Biol. Endocrinol. 28(5):26.

Eid L.N. 2004. Biometry of the buffalo gravid genitalia and related uterine components at different stages of pregnancy. Annals Agric. Sci. 42(1):41-52.

Feitosa Jr. F.S. 1997. Pesquisa anatômica sobre a ramificação e distribuição das artérias e veias da placenta em búfalos. São Paulo. Tese de Doutorado, Faculdade de Medicina Veterinária e Zootecnia, USP, São Paulo. 237p.

Miglino M.A. \& Didio L.J.A. 1994. Teofilovski-Parapid G. Allantoid duct, arteries and veins of the Funiculus umbilicalis in bovines. Revta Chilena Anat. 12(1):61-64.

Miglino M.A., Pereira F.T., Visintin J.A., Garcia J.M., Meirelles F.V., Rumpf R., Ambrósio C.E., Papa P.C., Santos T.C., Carvalho A.F., Leiser R. \& Carter A.M. 2007. Placentation in cloned cattle: Structure and microvascular architecture. Theriogenology 68(4):604-617.

Montané L. \& Bourdelle E. 1917. Anatomie Regionale des Animaux Domestiques. Tome 2xiéme, Ruminants. J.B. Baillière, Paris, p.53-61.

Morini A.C., Barbosa P.L.G., Melnic R.V., Morini-Junior J.C., Pereira F.T.V., Franciolli A.L.R., Martins D.S., Favaron P.O., Ambrósio C.E. \& Miglino M.A. 2008. Characterization of the fetal membranes in buffalo cows in the first three months of gestation. Pesq. Vet. Bras. 28(9):437445.

Noden D.M. \& De Lahunta A. 1985. Embriologia de los Animales Domésticos. Acribia, Zaragoza.

Ribeiro A.A.C.M. \& Miglino M.A. 1997a. O funículo umbilical em bovinos azebuados. Braz. J. Vet. Res. Anim. Sci. 34(5):266-269.

Ribeiro A.A.C.M., Miglino M.A. \& Didio L.J.A. 1997b. Pesquisa anatômica sobre o funículo umbilical em bovinos azebuados. Braz. J. Vet. Res. Anim. Sci. 34(5):321-326.

Santos D.A.S., Ricci R.E.G., Prado I.M.M., Carvalho A.F., Bombonato P.P., Ambrósio C.E., Teixeira D.G., Santos T.C., H.-Brazquez F.J., Martins D.S., Morini A.C., Kfoury Jr J.R. \& Miglino M.A. 2007. Morphology and morphometry of buffalo mammary papillae. Pesq. Vet. Bras. 27(3):95-102.

William K. \& Latshaw D.V.M. 1987. Veterinary Developmental Anatomy. B.C. Decker, Toronto. 521p. 